\title{
Peluang dan tantangan pemilu serentak 2019 dalam perspektif politik
}

\author{
Ratnia Solihah \\ Universitas Padjadjaran, Indonesia
}

\section{INTISARI}

Pemilihan Umum 2019 adalah pemilihan legislatif dengan pemilihan presiden yang diadakan secara serentak. Hal ini dilakukan berdasarkan Putusan Mahkamah Konstitusi Nomor 14 / PUU-11/2013 tentang pemilu serentak, yang bertujuan untuk meminimalkan pembiayaan negara dalam pelaksanaan pemilu, meminimalisir politik biaya tinggi bagi peserta pemilu, serta politik uang yang melibatkan pemilih, penyalahgunaan kekuasaan atau mencegah politisasi birokrasi, dan merampingkan skema kerja pemerintah. Pemilu serentak akan mempengaruhi komitmen penguatan partai politik dalam koalisi permanen untuk memperkuat basis kekuatan mereka di lembaga-lembaga negara yang tinggi sehingga dengan pemilu serentak diharapkan bisa memfasilitasi pembenahan Sistem Presidensial di Indonesia. Untuk mewujudkan pemilihan 2019 yang simultan, ada peluang dan tantangan yang salah satunya dapat dipelajari melalui perspektif politik, yang dalam makalah ini dilakukan melalui kajian pustaka dan dokumentasi. Menurut hasil penelitian, dalam mewujudkan pemilihan umum 2019 antara pemilihan legislatif dan pemilihan presiden, ada beberapa hal yang menjadi peluang dan tantangan dalam perspektif politik, baik untuk parpol, pemerintah, pemilih, dan penyelenggara pemilu. Untuk itu, diperlukan upaya-upaya terkait bagaimana merancang pemilihan yang serentak dalam perspektif politik, yakni dengan mereformasi sistem perwakilan, sistem pemilihan, sistem kepartaian, dan dalam melaksanakan pemilihan umum serentak 2019 memiliki tujuan menciptakan pemerintahan yang efektif.

\section{KATA KUNCI}

Pemilu Serentak 2019; Peluang dan Tantangan; Perspektif Politik

\section{Pendahuluan}

$\mathrm{P}$ ascaorde Baru, sistem pemilu Indonesia mengalami berbagai pergeseran. Sistem pemilu yang dianut di Indonesia saat ini adalah sistem pemilu yang dilakukan dalam tahapan pemilu legislatif (pileg), pemilu presiden (pilpres) serta pemilihan kepala daerah provinsi dan kabupaten/kota (pilkada). Pemisahan sistem pemilu tersebut, dinilai kurang efektif dan efisien

\section{Korespodensi:}

Departemen IImu Politik, Fakultas IImu Sosial dan IImu Politik, Universitas Padjadjaran, Jln. Raya Bandung Sumedang KM.21, Hegarmanah, Jatinangor, Kabupaten Sumedang, Jawa Barat 45363

Email: ratnia@unpad.ac.id 
dalam pelaksanaan pemilu yang menganut pemerintahan sistem presidensial, karena menimbulkan berbagai permasalahan, seperti konflik yang terus terjadi antara berbagai kepentingan kelompok maupun individu, pemborosan anggaran dalam penyelenggaraannya, maraknya politik uang, politisasi birokrasi, serta tingginya intensitas pemilu di Indonesia. Intensitas penyelenggaraan pemilu, pilpres dan pilkada yang terlampau sering tersebut berdampak pada rendahnya tingkat partisipasi sebagai akibat kejenuhan publik.

Persoalan lain dari format pemilu tersebut adalah fakta bahwa penyelenggaraan pemilu legislatif selalu mendahului pemilu presiden, padahal pada saat yang sama kita sepakat untuk memperkuat sistem presidensial. Pemilu legislatif yang mendahului pemilu presiden dalam skema presidensial jelas sebuah anomali, mengingat di dalam sistem presidensial lembaga eksekutif terpisah dari lembaga legislatif. Di sisi lain, penyimpangan ini beresiko pada implementasi sistem presidensial itu sendiri, baik dalam praktek politik dan pemerintahan. Salah satu resiko itu adalah berlangsungnya pencalonan pilpres yang "didikte" oleh hasil pemilihan legislatif. Artinya, tidak semua parpol bisa mengajukan pasangan calon untuk pemilihan umum presiden. Hanya parpol atau gabungan parpol yang memenuhi syarat ambang batas perolehan suara atau kursi minimal tertentu yang dapat mengajukan pasangan calon presiden dan wakil presiden. Untuk Pilpres 2009 dan 2014 misalnya, hanya parpol atau gabungan parpol yang memperoleh suara sekurangkurangnya $25 \%$ atau perolehan kursi DPR sekurang-kurangnya $20 \%$ yang dapa mengajukan pencalonan dalam pilpres.

Dengan demikian, nampak jelas bahwa baik pemilu legislatif (pileg) maupun pemilu presiden (pilpres) belum dirancang untuk memperkuat dan meningkatkan efektivitas pemerintahan presidensial. Pileg diselenggarakan hanya untuk sekedar mengisi keanggotaan lembaga-lembaga legislatif. Sementara pilpres dengan seluruh prosesnya dilaksanakan hanya untuk memilih presiden dan wakilnya tanpa dikaitkan dengan kebutuhan akan optimalisasi kinerja pemerintahan presidensial hasil pemilu itu sendiri. Singkatnya, tujuan governability atau terbentuknya pemerintahan yang dapat memerintah secara efektif, cenderung terabaikan dalam format pemilu-pemilu kita (Haris, dkk., 2014: 9-11).

Untuk menjawab berbagai permasalahan tersebut, diperlukan adanya terobosan kebijakan solutif berupa rumusan desain/format pemilu dengan hasil yang mampu menjamin terlaksananya efektivitas dan optimalisasi sistem presidensial yang responsif dan partisipatif. Selain itu dari segi teknis, desain/format tersebut mampu menjadi penawar atas kejenuhan publik. Sehingga pada akhirnya partisipasi masyarakat dalam demokrasi elektoral pun meningkat dengan harapan pemilu akan menjadi intermediant pewujudan demokrasi yang lebih substansial.

Terkait dengan kondisi tersebut, Mahkamah Kostitusi mengeluarkan Putusan Nomor 14/PUUXI/2013 Perihal Pengujian Undang-Undang Nomor 42 Tahun 2008 tentang Pemilihan Umum Presiden dan Wakil Presiden (selanjutnya Putusan Mahkamah Konstitusi, 2013), yang memiliki konsekuensi pemilu serentak pada Pemilu 2019. Namun pemilu serentak sebagai putusan MK tersebut dalam pandangan beberapa kalangan dirasa belum menjanjikan hasil pemilu yang mampu menjamin terciptanya pemerintahan yang stabil dan efisien, khususnya dalam upaya penguatan sistem presidensial yang selama ini diterapkan di Indonesia. Kemudian, dari segi teknis 
pelaksanaan belum tentu mampu menopang peningkatan angka partisipasi pemilih atau mampu menjadi penawar kejenuhan publik akibat dari intensitas pelaksanaan pemilu yang terlalu sering.

Berdasarkan hal di atas, melalui tulisan ini penulis akan membahas peluang dan tantangan mewujudkan pemilu serentak 2019 dalam perspektif politik, dengan melakukan kajian terhadap referensi dan dokumentasi yang terkait dengan permasalahan tersebut.

\section{Pembahasan}

Dalam kepustakaan ilmu politik terdapat prinsip-prinsip pilar sistem politik yang demokrasi, yaitu (1) jaminan hak dan kebebasan warga Negara; (2) partisipatory democracy; (3) sistem memilih dan mengganti penyelenggara Negara; (4) rule of law; (5) check and balance separation of power; (6) pemerintah dan oposisi yang efektif; (7) sistem pemerintahan daerah berdasarkan desentralisasi; (8) Korelasi Pemilu Serentak dengan Multi Partai Sederhana Sebagai Penguatan Sistem Presidensial paham konstitusionalisme; (9) pemerintahan oleh partai mayoritas; (10); budaya demokrasi (civic culture) sebagai sikap dan perilaku warga Negara (Surbakti, Supriyanto, \& Asy'ari, 2011).

Gaffar sebagaimana dikutip oleh (Shubhan, 2006: 43) memberikan parameter tentang sistem pemilu yang ideal, diantaranya: (1) demokrasi dalam sistem pemilu secara implisit dapat dilakukan secara adil dan jujur serta pemilu yang berkualitas; (2) out put pemilu harus berkualitas dan kompetitif serta akuntabilitas yang tinggi; (3) derajat keterwakilan dengan perimbangan antara pusat dan daerah; (4) peraturan perundang-undangan haruslah tuntas; dan (5) pelaksanaan pemilu bersifat praktis dan konkrit.

Surbakti, dkk. (2011: 49-51) mengemukakan bahwa Pemilu legislatif pusat maupun daerah, seyogyanya memenuhi unsur berikut ini: (1) sesuai dengan ketentuan UUD 1945; (2) menghasilkan sistem parpol pluralism moderat; (3) menciptakan keseimbangan sistem representasi penduduk; (4) menghasilkan sistem representasi penduduk; (5) menjamin keterwakilan perempuan dan minoritas; (6) soliditas dukungan terhadap presiden; (7) menghilangkan tindakan manipulatif; dan (8) sistem pemilu yang simpel.

Berkaitan dengan hal tersebut, Surbakti, dkk. (2011:8) memberikan pandangan tentang sistem pemilu legislatif. Menurutnya, Sistem pemilu legislatif dalam pemilihan umum dibagi atas tiga sistem utama, yaitu: (1) sistem mayoritarian. Sistem mayoritarian merupakan sistem yang menyediakan satu kursi atau single constituency dalam daerah pemilihan, dan ditentukan oleh perolehan suara terbanyak; (2) sistem proporsional, yaitu kebalikan dari sistem mayoritarian. Setiap daerah pemilihan tersedia banyak kursi dengan perolehan kursi parpol secara proporsional dengan ketentuan jumlah suara terbanyak; dan (3) sistem semiproporsional merupakan gabungan kedua sistem di atas.

Sedangkan dalam pemilu presiden dan wakil presiden, sistem dilakukan dengan dua cara, yaitu. Pertama, pemilu secara langsung (populary elected) adalah calon yang mendapatkan suara terbanyak ditetapkan sebagai presiden terpilih, Sedangkan dalam pemilu tidak langsung (electoral college) adalah dilakukan melalui porsi suara wakil rakyat (DPRD Provinsi atau DPRD Kabupaten/ Kota) yang menjadi representasi rakyat dalam pemilihan umum presiden dengan perolehan suara 
lebih $50 \%$. Calon yang memperoleh suara terbanyak ditetapkan sebagai pemenang dalam pemilu secara langsung. Sedangkan dalam pemilu tidak langsung. Calon yang menempatkan $50 \%$ wakilnya yang akan terpilih menjadi presiden (Surbakti, dkk., 2011: 9).

Geys sebagaimana dikutip (Haris, dkk., 2014: 15) menyebutkan bahwa secara umum, pemilu serentak atau lazim juga disebut sebagai pemilu konkuren (concurren elections) adalah pemilu yang diselenggarakan untuk memilih beberapa lembaga demokrasi sekaligus pada satu waktu secara bersamaan. Jenis-jenis pemilihan tersebut mencakup pemilihan eksekutif dan legislatif di beragam tingkat di negara yang bersangkutan, yang terentang dari tingkat nasional, regional, hingga pemilihan di tingkat lokal.

Dalam penggunaan desain pemilu serentak, praktek yang banyak digunakan adalah penggabungan antara pemilihan eksekutif dengan pemilihan legislatif. Desain ini banyak digunakan di negara-negara Amerika Latin. Bukan hanya untuk tingkat nasional, pemilu serentak di beberapa negara juga dilakukan dengan menggabungkan antara pelaksanaan pemilu nasional dengan pemilu regional atau lokal. Di Amerika Serikat misalnya, di beberapa negara bagian, pemilu bukan hanya memilih presiden, anggota kongres dan senat di tingkat pusat, melainkan dalam waktu bersamaan juga menyelenggarakan pemilihan gubernur dan legislator di tingkat negara bagian (Haris, dkk., 2014: 16).

Hanan (2016: 1471) mengemukakan bahwa pelaksanaan pemilu serentak belum tentu akan berdampak positif terhadap penguatan sistem presidensial multipartai. Ada banyak variabel yang harus dikombinasikan, kombinasi sistem pemilu seperti plurality dan Majority Run Off (MRO). Dampaknya bisa berbeda bila dikombinasikan dengan pemilu eksekutif-legislatif serentak. Temuan umum dalam berbagai riset, terutama dari sistem presidensial multipartai di Amerika Latin menunjukkan bahwa gabungan sistem pemilu presiden dengan formula plurality dengan pemilu legislatif secara serentak cenderung dapat membantu penyederhanaan sistem kepartaian. Tetapi ini tetap tergantung misalnya kepada berapa jumlah kandidat presiden yang bertarung. Bila kandidat presidennya banyak, maka dampak reduktif dari sistem plurality terhadap sistem kepartaian legislatif cenderung memudar.

Pandangan lain menyebutkan bahwa keserentakan pelaksanaan pemilu merupakan suatu formula alternatif bagi perubahan sistem politik dan pemerintahan. Hal ini didasarkan pada pengalaman dan upaya untuk mengatasi berbagai problematika yang ada, yaitu: (1) menjadi dasar bagi terealisasinya sistem pemerintahan presidensialisme yang kuat dan stabil; (2) memfasilitasi munculnya penyederhanaan sistem kepartaian, melalui pemberian insentif bagi partai politik untuk membangun budaya dan pelembagaan politik demokratis yang berkelanjutan (Aliansi, Koalisi, Gabungan, dan atau Merger); (3) mendorong pembentukan parlemen yang lebih efektif; (4) Menciptakan sistem pemilihan yang lebih sederhana, waktu yang singkat, sekaligus biaya murah baik dalam pemilu legislatif maupun pemilihan umum presiden; (5) Menciptakan ruang bagi munculnya fokus isu dalam pemilu, mana yang merupakan isu nasional dan mana isu lokal; (5) Membuka ruang partisipasi bagi menguatnya preferensi dan strategi rakyat (pemilih) pada pemilu berdasarkan isu lokal maupun nasional; (6) Agar tujuan-tujuan di atas dapat terealisir secara efektif, maka sistem pemilu presiden runnof with a reduced threshold (mayoritas bersyarat) 
merupakan pilihan utama. Adapun persyaratan yang diterapkan adalah; pasangan PresidenWakil Presiden terpilih pada putaran pertama, jika meraih $45 \%$ suara dengan jarak 5 persen dari kandidat kedua, atau $40 \%$ suara dengan jarak $10 \%$ suara dari kandidat kedua (Wijayanti \& Purwaningsih, 2015: 51).

Desain pemilu serentak di kebanyakan negara lain seperti dikemukakan oleh Jones dan banyak peneliti lain di Amerika Latin (Wijayanti \& Purwaningsih, 2015: 52) menyatakan bahwa sistem pemilu legislatif dan eksekutif dalam sistem presidensial multipartai haruslah mengkombinasikan waktu pelaksanaan yang serentak, sistem Proporsional dalam pemilu legislatif, dan sistem plurality dalam menentukan pemenang pemilu presidennya. Sistem plurality sendiri sebetulnya cenderung menghasilkan sedikit kandidat presiden. Ketika pemilu presiden para pendukung kandidat dalam sistem ini cenderung mengabaikan Para kandidat yang tidak kompetitif (nonaviable) supaya mereka dapat fokus pada dua kandidat teratas. Hal ini mendorong proses koalisi antar partai sejak awal karena hanya ada satu putaran pemilihan. Partai yang mestinya mengajukan calon sendiri namun calonnya kurang kompetitif cenderung akan mendrop calonnya dan meng-endorse satu di antara dua calon paling kompetitif dengan harapan akan mendapatkan konsesi politik pasca pemilu presiden. Dampak - reduktif dari sistem plurality menjadi tidak berpengaruh terhadap penyederhanaan partai di legislatif, dengan asumsi pemilu legislatif dilaksanakan dengan sistem proporsional. Mekanisme plurality ini berpengaruh terhadap partai-partai ketika dilaksanakan serentak dengan pemilu legislatif. Partai-partai cenderung akan mencalonkan salah satu dari dua kandidat paling kompetitif, dan berujung pada mengumpulnya dukungan partai-partai legislatif pada dua kandidat tersebut. Ketika salah satu dari kandidat itu memenangkan pemilu presiden, maka dukungan terhadap presiden tersebut di legislatif cenderung akan mayoritas atau mendekati mayoritas. Dengan demikian gabungan sistem pemilu presiden plurality yang dilaksanakan serentak dengan pemilu legislatif adalah yang paling mungkin membantu penguatan sistem presidensial multipartai.

Sistem pemilu presiden dengan majority runoff, di sisi lain, cenderung memiliki dampak inflationary terhadap jumlah partai, sekalipun dilaksanakan serentak dengan pemilu legislatif. Partai dan kandidat yang berkompetisi dalam sistem ini lebih terfokus pada bagaimana maju ke putaran kedua. Selama tidak ada kandidat yang sangat dominan maka seorang kandidat yang memperoleh minimal sepertiga dari suara punya kemungkinan untuk maju ke putaran kedua (Wijayanti \& Purwaningsih, 2015: 52).

Putusan Mahkamah Konstitusi (MK) No.14/PUU-XI/2013 merupakan pengujian Pasal 3 ayat (5), Pasal 12 ayat (1) dan ayat (2), Pasal 14 ayat (2), dan Pasal 112 Undang-Undang No.42 Tahun 2008 tentang Pemilihan Umum Presiden dan Wakil Presiden. Beberapa pasal tersebut mengatur ketentuan Pemilu Anggota Lembaga Perwakilan dan Pemilihan Presiden yang dilaksanakan terpisah. Namun berdasarkan putusan Mahkamah Konstitusi, ketentuan beberapa pasal tersebut dinyatakan bertentangan dengan UUD 1945 dan tidak mempunyai kekuatan hukum mengikat. Implikasi dari pembatalan tersebut adalah dilaksanakannya Pemilihan Umum Nasional Serentak atau Pemilu Anggota Lembaga Perwakilan dan Pemilihan Presiden dilakukan secara serentak yang dimulai pada tahun 2019 dan tahun-tahun selanjutnya (Putusan Mahkamah Konstitusi, 2013: 85-87). 
Dalam perspektif politik, munculnya Putusan Mahkamah Konstitusi (2013) tersebut, dapatlah dapatlah ditelusuri melalui penyelenggaraan Pilpres tahun 2004 dan tahun 2009 yang dilakukan setelah Pemilu legislatif, dimana dalam pemilu tersebut ditemukan fakta politik bahwa untuk mendapat dukungan demi keterpilihan sebagai Presiden dan dukungan DPR dalam penyelenggaraan pemerintahan, jika terpilih, calon Presiden terpaksa harus melakukan negosiasi dan tawar-menawar (bargaining) politik terlebih dahulu dengan partai politik yang berakibat sangat mempengaruhi jalannya roda pemerintahan di kemudian hari. Negosiasi dan tawar-menawar tersebut pada kenyataannya lebih banyak bersifat taktis dan sesaat daripada bersifat strategis dan jangka panjang, misalnya karena persamaan garis perjuangan partai politik jangka panjang. Oleh karena itu, Presiden pada faktanya menjadi sangat tergantung pada partai-partai politik sehingga dapat mereduksi posisi Presiden dalam menjalankan kekuasaan pemerintahan menurut sistem pemerintahan presidensial.

Untuk itu, penataan sistem pemilu oleh Mahkamah Konstitusi bertujuan agar sistem pemilu lebih baik dan mampu melahirkan presiden dan wakil presiden yang berkualitas, serta mampu menyelesaian persoalan bangsa dan negara. Pilpres yang dilakukan setelah Pemilu Legislatif (Pemilu tidak serentak) telah menyebabkan sistem pemilu dan sistem pemerintahan presidensiil keluar dari rel konstitusi, sehingga untuk mengembalikan hal tersebut pada sistem yang benar menurut konstitusi harus dengan membatalkan beberapa ketentuan Pasal dalam UU Pilpres yang mengatur hal tersebut.

Menurut Prasetyoningsih (2014: 254), putusan Mahkamah Konstitusi ini merupakan putusan yang baik dan sangat acceptable, dengan berbagai argumentasi bahwa: (1) pemilu yang tidak serentak justru tidak memperkuat sistem pemerintahan presidensiil; (2) pemilu serentak merupakan amanat konstitusi, (3) dan tentunya akan mengarah pada efektivitas dan efisiensi penyelenggaraan pemilihan umum, serta hak warga negara untuk memilih secara cerdas, sehingga pemilu serentak memang akan lebih efisien dan pembiayaan penyelenggaraannya.

Selain itu, merujuk pada pemilu 2009 dan pemilu 2014, sebagai referensi pengalaman pelaksanaan pemilu yang tidak serentak, dengan sistem pemilu yang memisahkan pelaksanaan pemilu legislatif dengan pemilu presiden, memunculkan berbagai permasalahan sebagaimana dikemukakan Surbakti, dkk. (2011: 21-22), yaitu: (1) DPT bermasalah; (2) kualitas hasil pemilu tidak efektif; (3) pelayanan yang kurang maksimal; (4) kompleksitas sistem pemilu; (5) penentuan calon tidak melibatkan warga negara yang masuk dalam partai politik; (6) menurunnya pengawasan; (7) sistem konversi surat suara; (8) representasi tidak terarah; (9) terbatasnya partisipasi politik; dan (10) penilaian kinerja terhadap wakil rakyat tidak efektif.

Sistem parpol pasca reformasi menjadi indikasi dari mahalnya ongkos politik dalam sistem pemilu di indonesia. Menjamurnya parpol pasca reformasi, menciptakan organisasi partai politik tidak terkendali dengan munculnya figur-figur politisi baru dalam gerbong politik baru pula. Hal itu dipengaruhi oleh mudahnya mendapatkan legalitas untuk menjadi peserta pemilu.

Terkait dengan kondisi tersebut, maka dapatlah dilihat bahwa pelaksanaan sistem pemilu legislatif (pileg) dan sistem partai politk selama ini memunculkan berbagai permasalahan, seperti mahalnya ongkos penyelenggaraan, politik biaya tinggi atau politik uang, konflik antar caleg 
maupun antar kelompok kepentingan, politisasi birokrasi, korupsi, instabilitas dan tidak efektifnya pemerintahan.

$\mathrm{Hal}$ tersebut sejalan dengan pemikiran Hayat (2014: 472), bahwa sistem pemilu legislatif yang diterapkan saat ini banyak menimbulkan problematika di masyarakat, money politic, mobilisasi massa pelibatan anak-anak, kecurangan dalam pelaksanaan pemilu, hingga menghalalkan segala cara untuk memenangkan pemilu, dan irrasionalitas dari para caleg dalam ikhtiar pemilu, hingga menghilangkan prinsip keadilan dan kesetaraan. Tidak sedikit gejolak kerusuhan, pertikaian, dan pertengkaran diantara masyarakat seolah-olah menjadi pembiasaan di kalangan masyarakat sebagai faktor dari sistem pemilu yang dianut.

Di parlemen, partai politik membawa misi dan visi partai sebagai bentuk kebijakan bagi publik dalam realisasi pemerintahan, sehingga partai politik di parlemen tidak proporsional dalam melaksanakan tugas dan fungsinya, yaitu di dalam kepemerintahan, baik sebagai oposisi atau koalisi. Selain itu, perpecahan koalisi dalam pemerintahan sebagai faktor lemahnya soliditas parlemen di pemerintahan dengan berbagai kepentingan individu ataupun kelompok tertentu menjadikan kebijakan yang dipolitisir untuk mencitrakan dan mendapatkan keuntungan dan pencitraan, sehingga menjadi pelemahan sendiri dalam praktek-praktek pemerintahan dengan menciptakan inkondusifistik terhadap sistem presidensial.

Selama ini Pemilihan umum presiden yang diselenggarakan setelah Pemilihan legislatif menghasilkan koalisi parpol yang rapuh (tidak kuat). Pengalaman menunjukkan bahwa pemerintahan yang dihasilkan dalam 4 (empat) kali Pemilu pasca reformasi sering mengalami pemerintahan yang "terbelah" (devided government). Hal ini ditandai oleh beberapa keadaan, antara lain: Mekanisme saling mengawasi dan mengimbangi antara DPR dan Presiden kurang berjalan dengan baik; Pasangan calon Presiden dan Wakil Presiden kerap menciptakan hubungan kemitraan taktis yang bersifat sesaat dengan partai politik, sehingga tidak melahirkan gabungan kerjasama antarpartai politik berjangka panjang yang dapat melahirkan penyederhanaan jumlah partai politik secara alamiah; Dalam praktik, model pengusulan pasangan calon Presiden dan Wakil Presiden oleh gabungan partai politik tidak selalu membentuk gabungan kerjasama yang bersifat permanen dari partai-partai politik di parlemen, sehingga tak kunjung mampu mewujudkan penyederhanaan sistem kepartaian kita. Malah sistem kepartaian kita semakin terfragmentasi.

Pemilu Serentak merupakan jawaban atas berbagai persoalan di atas. Dalam pemilu serentak kemenangan calon presiden cenderung diikuti perolehan kursi mayoritas parlemen partai atau gabungan partai pengusungnya. Demikian pula sebaliknya. Pemilu serentak akan menciptakan gabungan kerjasama antarpartai politik dalam pemerintahan yang solid karena proses pembentukannya tersedia cukup waktu.

Dalam pemilu yang dipisahkan pelaksanaannya antara pileg dan pilpres dapat dilihat bahwa pembentukan gabungan kerjasama (koalisi) antarpartai politik selama ini, semua partai menunggu hasil pileg yang jaraknya hanya satu bulan dari jadwal pencalonan presiden dan wakil presiden. Pembentukan gabungan kerjasama (koalisi) antarpartai politik dalam menghadapi pilpres saat ini pun berlangsung cair dan cenderung tidak berpola. Gabungan kerjasama (koalisi) tersebut akan terbentuk di menit-menit akhir karena desakan waktu. Ada penggabungan sebelum pilpres, lalu 
ada partai bergabung pada putaran kedua, dan ada pula partai masuk lagi setelah pilpres selesai untuk ikut gabung dalam pemerintahan. Akibatnya, bangunan gabungan kerjasama (koalisi) yang dihasilkan menjadi rapuh. Partai yang pertama bergabung merasa berhak mendapatkan kursi kabinet lebih banyak. Sementara partai lain meskipun bergabung belakangan juga merasa memiliki hak serupa karena punya kursi di parlemen. Bahkan lalu ada partai yang meminta anggota legislatifnya untuk ikut mencampuri pemerintahan di mana mereka ikut di dalamnya.

Pemilu selama ini yang pelaksanaannya dipisahkan antara pemilihan umum legislatif (pileg) dan pemilihan umum presiden (pilpres) juga menunjukkan bahwa pemenang pemilu eksekutif (pilpres) tidak berbanding lurus dengan pemenang pemilu legislatif (pileg), sehingga eksekutif tidak mendapat dukungan yang memadai dari legislatif. Melalui pemilu serentak, dimana Pilpres dan Pileg dilaksanakan serentak nantinya diharapkan melahirkan koalisi jangka panjang. Selain itu, dalam jangka panjang, dengan dilaksanakannya pemilu serentak diharapkan dapat menyederhanakan pola kepartaian yang dibutuhkan sistem presidensial. Hal itu karena gabungan kerjasama antarpartai politik yang terbentuk, baik yang menang maupun yang kalah dalam persaingan pemilu cenderung menjadi permanen. Tentu ada kemungkinan partai yang berubah mitra-koalisi di tengah perjalanan, tapi jumlahnya minim saja. Partai-partai besar cenderung bertahan dan mapan pada posisinya. Sementara partai-partai kecil yang tidak punya calon presiden hebat akan berkurang dengan sendirinya.

Selain itu, kedudukan konstitusional partai politik dalam pemilu sangat strategis. Partai politik disebut sebagai peserta pemilu (Pasal 22E), dan dalam kedudukannya sebagai peserta pemilu itu partai politik adalah satu-satunya institusi yang diberi hak untuk mengusulkan pasangan capres/ cawapres (Pasal 6A). Jadi dapat disimpulkan bahwa gagasan pemilu dalam UUD 1945 pasca perubahan adalah pemilu serentak berbasis partai politik.

Pemilu serentak memerlukan modifikasi (perubahan) pada sistem pemilihan legislatifnya. Tanpa perubahan sistem, Pemilu 2019 bisa lebih buruk kualitasnya dibanding dengan Pemilihan legislatif 2014. Tanpa penyempurnaan sistem, Pemilu 2019 bisa menjadi ajang lebih maraknya praktek politik uang (money politics), gagal mewujudkan sistem presidensial yang dicita-citakan, dan akibatnya akan mendistorsi implementasi ketentuan konstitusi yang terkait dengan kedaulatan rakyat.

Sistem pemilihan legislatif di Indonesia seharusnya kembali kepada semangat konstitusi yang telah menetapkan partai politik sebagai peserta pemilu. Pemilu proporsional terbuka berbasis calon legislator (caleg) harus dikembalikan menjadi berbasis partai politik yang merupakan peserta pemilu. Perubahan ini dapat mengatasi kelemahan sistem pemilu kita saat ini seperti maraknya politik uang, 'perang-saudara' antar caleg, kecurangan-kecurangan yang dilakukan baik oleh peserta maupun penyelenggara/dan atau dilakukan oleh peserta dan penyelenggara. Sistem proporsional berbasis partai politik ini juga berkesesuaian dengan pola pemerintahan presidensial. Dengan sistem proporsional berbasis partai politik, maka partai politik yang melakukan kampanye dan pemilih hanya memilih partai politik, bukan memilih calon anggota legislatif (caleg) secara langsung. Para caleg mendukung partai politiknya berkampanye, dengan mengangkat isu-isu yang jelas dan terarah. Mereka tidak perlu melakukan kampanye sendiri-sendiri dengan mengangkat isu-isu pribadi yang justru membingungkan. Lebih dari itu, pemilih dapat dimudahkan dalam menentukan pilihan. 
Oleh karenanya, syarat mutlak kembalinya pemilihan umum legislatif (pileg) kepada sistem proporsional berbasis partai politik harus diikuti dengan perbaikan sistem rekruitmen bakal calon legislator (caleg) dan bakal calon presiden-calon wakil presiden (capres-cawapres) oleh partai politik. Partai politik harus memberi jaminan kepada masyarakat bahwa caleg-caleg mereka adalah caleg yang memiliki kapabilitas, kapasitas dan figur wakil rakyat yang baik dan amanah, bukan caleg dari hasil praktik oligarki. Hal itu dapat dilakukan dengan perintah UU. Setiap partai politik peserta Pemilu wajib menyelenggarakan pemilu internal untuk memilih bakal caleg dan bakal capres yang akan dikirim untuk mengikuti Pemilu 2019. Undang-Undang harus mengatur aturan yang rinci dan tegas terkait hal ini dengan memberikan sanksi diskualifikasi bagi partai politik yang tak mentaatinya.

Implikasi yang diharapkan dari adanya pemilu serentak adalah efisiensi pelaksanaan pemilu disertai efektivitas yang mengikutinya, yang dapat menekan pengeluaran dana negara dalam pemilu. Dengan pemilu serentak, maka partai politik dituntut untuk menyederhanakan sistem parpol dengan multi partai sederhana, sehingga tingkat relevansinya antara sistem pemilu dan sistem parpol dapat berjalan beriringan dengan penguatan terhadap sistem presidensial, yang berdampak kepada konsepsi kebijakan-kebijakan pemerintah yang didukung secara penuh dan solid dalam parlemen terhadap penyelenggaraan pemerintahan di Indonesia.

Selain itu, hasil pemilu dengan sistem serentak dapat dilihat secara relevan antara anggota legislatif terpilih dengan presiden terpilih terhadap penguatan sistem presidensial. Presiden sebagai kepala negara dapat melakukan fungsinya terhadap sistem presidensial secara sistematis korelatif dengan integrasi yang signifikan dalam kerjasama dengan DPR. DPR menjadi penguat dalam sistem presidensial terhadap kebijakan-kebijakan pemerintah. Presiden dapat melaksanakan wewenang presidensialnya dengan dukungan yang sangat kuat di parlemen sebagai penyangga pemerintahan melalui tugas pokok dan fungsinya sebagai legislator. Oleh karenanya, sistem pemilu serentak harus didukung oleh sistem multipartai sederhana sebagai komponen penting dalam pemilu.

Dalam mewujudkan pemilu serentak 2019 berdasarkan Keputusan Mahkamah Konstitusi Nomor 14/PUU-XI/2013 tentang pelaksanaan pemilu serentak, muncul penafsiran bahwa Pemilu 2019 akan diselenggarakan dengan 5 kotak. Secara sederhana putusan itu banyak dimengerti sebagai sekedar perbedaan dalam penyelenggaraannya dimana Pemilu 2019 akan diselenggarakan secara bersamaan untuk memilih DPR, DPD, DPRD, Presiden dan Wakil Presiden. Namun demikian, apapun yang diputuskan oleh Mahkamah Konstitusi terkait dengan Pemilu Serentak itu, sebaiknya direspons secara akademik dan dilihat pengaturan teknis implementatif yang harus ada beserta pernik-perniknya. Dengan kata lain perlu disiapkan tata kelola penyelenggaraannya dalam pemilu serentak tersebut.

Ketika Mahkamah Konstitusi (MK) memutuskan untuk penyelenggaraan Pemilu Serentak, Putusan Mahkamah Konstitusi (2013) masih belum berupa putusan operasional yang menjawab kekhawatiran atas berbagai permasalahan dalam penyelenggaraan pemilu selama ini. Berbagai alasan seperti: agar masyarakat pemilih tidak jenuh, meminimalisir politik uang, meminimalisir politisasi birokrasi dan untuk efisiensi dalam penyelenggaraannya mungkin bisa terjawab oleh 
Pemilu Serentak. Terlepas dari itu, penyelenggaraan Pemilu Serentak tahun 2019 sesuai Putusan Mahkamah Konstitusi (2013), masih belum mengatur peraturan operasionalisasinya yang bisa memperkuat sistem presidensial, karena Pemilu Serentak dalam Putusan Mahkamah Konstitusi (2013) adalah pemilu yang lebih tepatnya penyelenggaraannya diserentakkan, 5 kotak. Ini yang kemudian yang dikhawatirkan tidak mengakibatkan munculnya coattail effect. Coattail effect ini secara teori sebenarnya mengatur hubungan sequential dimana partai yang menjadi pemenang pada pemilu legislatif adalah partai dimana presiden dan wakil presiden terpilih berasal. Pola Coattail effect ini akan memperkuat evaluasi terhadap kinerja partai sekaligus memberi peluang kepada partai politik untuk bekerja lebih bagus lagi agar pemilih memilih calon yang berasal dari partai yang sama (Madariaga \& Ozen, 2015: 66-75) (Madariaga \& Ozen, 2015. Yang dikhawatirkan adalah bahwa Pemilu Serentak ini adalah pemilu yang diserentakkan penyelenggaraannya saja, tetapi tidak sampai menyentuh coattail effect itu tadi.

Hal di atas berbeda dengan pemikiran Fiorina yang menekankan faktor waktu pemilihan anggota parlemen dan presiden sebagai faktor utama penyebab terjadinya divided government sebagai akibat tidak terjadinya coattail effects. Menurutnya, pemerintahan terbelah terjadi ketika anggota legislatif dan pejabat eksekutif dipilih pada periode waktu yang berbeda dan atau cara yang tidak sama. Jadi, terjadinya divided government bukan karena faktor penggunaan sistem multipartai dan pemilu proporsional. Sistem dwipartai dan pemilu mayoritarian pun juga sama berpeluang menyumbangkan terjadinya mayoritas legislatif yang tidak sama dengan parpol pendukung presiden (Wijayanti \& Purwaningsih, 2015: 44). Dengan demikian, dalam menciptakan pemerintahan presidensial efektif, masalahnya bukan mengganti sistem multipartai dan pemilu proporsional dengan sistem dwipartai dan pemilu mayoritarian, melainkan bagaimana mendesain sistem kepartaian dan sistem pemilu yang ada agar dapat menghindari terjadinya divided government sehingga terbentuk pemerintahan efektif. Salah satunya adalah melakukan penataan pemilu serentak eksekutif dan legislatif, sebab dalam pemilu serentak sangat dimungkinkan munculnya coattail effects.

Pemikiran Fiorina tersebut sejalan dengan tesis Shugart (dalam Wijayanti \& Purwaningsih, 2015: 44), bahwa jika waktu penyelenggaraan pemilu presiden diserentakkan (simultan) dengan pemilu legislatif akan menimbulkan coattail effect, yaitu (hasil) pemilihan umum presiden akan mempengaruhi (hasil) pemilihan umum legislatif. Artinya, pemilih akan memilih presiden sekaligus parpol (koalisi parpol) pendukung presiden. Tesis Shugart ini ternyata berlaku di Brasil setelah mereka melakukan perubahan jadwal pemilu, yaitu dengan menyerentakkan waktu penyelenggaraan pemilu presiden dan pemilu anggota legislatif. Tesis coattail effect menunjukkan bahwa faktor waktu penyelenggaraan pemilu bisa mengatasi masalah tidak harmonisnya hubungan eksekutif legislatif.

Jika waktu penyelenggaraan pemilu presiden bersamaan dengan pemilu legislatif, pemilihan umum presiden akan mempengaruhi pemilihan umum legislatif. Artinya, pemilih akan memilih presiden dan memilih parpol pendukung presiden. Pemilu serentak dapat juga dirancang untuk memberikan efek dari satu pemilihan ke pemilihan lainnya. Biasanya yang menjadi pertimbangan adalah untuk mempengaruhi hasil pemilihan umum presiden dengan menggunakan hasil pemilihan legislatif sebagai salah satu dasar penentuan pemenang. Dengan aturan tertentu, bisa disusun 
adanya pengaruh perolehan suara partai tertentu dengan syarat kemenangan kandidat presiden partai tersebut, sehingga satu jenis pemilihan akan memiliki efek mekanis terhadap hasil pemilihan lainnya. Partai dengan perolehan suara terbanyak maka dapat mengantarkan kandidat presidennya untuk menduduki kursi kepresidenan meski hasilnya di pemilihan presiden belum tentu yang paling baik. Dalam varian tertentu, efek mekanistis diharapkan terjadi dalam rentang waktu tertentu, seperti halnya yang lazim disebut sebagai coattail effect sebagaimana dijelaskan di atas.

Dengan demikian pemerintah akan efektif berkerja karena presiden mendapat dukungan penuh dari parlemen. Itu bukan berarti presiden bekerja tanpa kontrol, sebab parpol-parpol yang calon presidennya kalah dengan sendirinya menjadi oposisi. Sebagai parpol oposisi, apabila mereka tidak menjalankan fungsi oposisi secara maksimal, baik dalam mengkritisi pelaksanaan kebijakan maupun dalam menawarkan alternatif kebijakan, pada pemilu berikutnya mereka akan kalah lagi.

Pemilu serentak dianggap akan mengurangi kelemahan-kelemahan praktek politik yang selama ini terjadi. Ada beberapa peluang dengan dilaksanakannya pemilu serentak antara pilpres dengan pileg, baik bagi pemilih, partai politik, pemerintah, dan bagi penyelenggara pemilu, antara lain:

\section{Peluang dan Tantangan bagi Pemilih.}

Untuk melihat peluang, hal ini merujuk pada pendapat para ilmuan bahwa pemilu serentak akan meningkatkan partisipasi pemilih. Menurut Norris, pemilih dalam pemilihan umum legislatif lebih rendah jika pemilihan umum legislatif dan pemilihan umum presiden dilaksanakan secara terpisah (Stockemer \& Calca, 2014: 564). Menurunnya suara dalam pemilihan umum legislatif karena menganggap bahwa pemilihan umum presiden lebih penting daripada pemilihan umum legislatif. Menurunnya jumlah pemilih dalam pileg, karena pemilih harus datang ke TPS dua kali yang tentunya akan membutuhkan biaya, termasuk juga biasa untuk mencari informasi mengenai isu dan kandidat dari kedua pemilihan. Adanya biaya yang harus dikeluarkan tersebut mencegah pemilih untuk datang ke TPS, khususnya dalam pileg yang dianggap kurang penting.

Di Indonesia, pemilu anggota legislatif dilaksanakan terlebih dahulu dari pemilu presiden. Tingkat partisipasi politik dari masyarakat pada pemilu legislatif dalam pemilu 2009 sebesar $71 \%$, sementara dalam pilpres turun menjadi 72,09\%. Sedangkan dalam pemilu 2014, partisipasi pemilih dalam pemilu anggota legislatif sebesar $75,1 \%$ sedangkan dalam pemilihan umum presiden sebesar 69,58\% (Purnamasari, 2017). Penurunan tingkat partisipasi pemilih ini bisa dihindari apabila dilaksanakan pemilu serentak. Dengan demikian, pemilu serentak antara pileg dan pilpres akan meningkatkan partisipasi. Argumen pemilu serentak akan meningkatkan partisipasi pemilih, selain alasan efisiensi waktu, tenaga dan biaya dari pemilih yang dikeluarkan untuk datang ke TPS. Riker dan Ordeshook (dalam Stockemer \& Calca, 2014: 564) menyatakan bahwa pemilu serentak akan memberikan dorongan psikologis, yaitu mereka menilai bahwa mereka memilih dua pejabat tinggi secara serentak.

Sedangkan untuk melihat tantangan, meskipun pemilu serentak akan meningkatkan partisipasi pemilih dan efisiensi waktu, tenaga dan biaya untuk datang ke TPS, namun pelaksanaan pemilu serentak yang memilih beberapa pejabat politik sekaligus membutuhkan waktu yang lebih banyak dalam bilik suara. Paling tidak terdapat 5 kertas suara yang harus dipilih yaitu pasangan calon 
presiden dan wakil presiden, anggota DPR Rl, anggota DPD RI, anggota DPRD Provinsi dan anggota DPRD Kabupaten/Kota. Selain terdapat 5 kertas suara yang harus dipilih, pemilu proporsional yang memilih calon menjadikan kertas suara cukup besar, sehingga waktu yang dibutuhkan untuk membuka dan melipat kembali menjadi lebih banyak. Selain itu, pemilu serentak membawa kesulitan bagi pemilih dalam menentukan pilihannya karena informasi yang diterima menjadi sangat banyak, namun kemampuan untuk mengolah informasi terbatas sehingga pemilih cenderung untuk memilih kandidat nasional dengan isu-isu nasional. Oleh karena itu, perlu upaya sosialisasi dan pendidikan pemilih yang serius dari penyelenggara pemilu untuk meningkatkan kesadaran politik dari pemilih.

\section{Peluang dan Tantangan bagi Pemerintah (Presiden dan DPR)}

Pemilu serentak memberikan peluang bagi terciptanya system pemerintahan presidensial yang lebih kuat dan stabil. Hal ini karena koalisi yang dibentuk dalam mengusung pasangan calon Presiden dan Wakil Presiden dilakukan lebih awal dan didasarkan kepada visi misi yang sama, tidak semata-mata untuk memenangkan pemilihan.

Hal ini sebagaimana dinyatakan oleh Reynolds, Reilly, \& Ellis (2008: 124) bahwa pemilu serentak menguntungkan partai pendukung presiden, dan mengurangi fragmentasi antara legislatif dan eksekutif. Dengan demikian maka koalisi yang dibangun akan menjadi lebih solid. Koalisi yang memperoleh dukungan mayoritas di parlemen dan memenangkan pilpres kemungkinan akan berjuang untuk memenangkan pilkada. Kekuasaan yang sama pada level nasional dan lokal akan memudahkan presiden dalam melakukan koordinasi dan penyelenggaraan pemerintahan yang berjenjang sehingga pemerintahan juga akan lebih efektif.

Adapun tantangannya, dalam menciptakan koalisi yang solid dan berbasis visi misi, diperlukan penyederhanaan sistem kepartaian. Penyederhanaan sistem kepartaian akan bisa terwujud apabila diawali dengan perbaikan sistem pemilu. Selain itu, diperlukan sinkronisasi peraturan mengenai pemilu serentak, baik UU tentang partai politik, UU pemilihan umum maupun UU pemilihan umum presiden dan Wakil Presiden.

\section{Peluang dan Tantangan bagi Partai Politik}

Dengan peluang adanya pemilu serentak, partai politik bisa melaksanakan fungsi-fungsinya secara lebih efisien. Waktu, tenaga dan biaya yang dibutukan oleh partai politik untuk kampanye menjadi lebih efisien karena dilakukan secara bersamaan. Koalisi dalam mengusung pasangan calon Presiden dan Wakil Presiden bisa dilakukan lebih awal. Partai politik, bahkan partai kecil sekalipun mempunyai peluang yang sama dalam mengusung pasangan calon Presiden dan Wakil Presiden. Pasangan capres dan cawapres yang popular dan bisa diterima oleh partai-partai yang lain merupakan cara untuk mendongkrak suara partai dan memenangkan pemilu.

Sedangkan tantangannya, partai politik harus mampu menawarkan pasangan calon Presiden dan Wakil Presiden yang populer dan bisa diterima oleh partai-partai yang lain untuk memperoleh dukungan dari koalisi partai yang akan dibentuk. Setiap sistem pemilu membawa konsekuensi bagi partai politik, sehingga pemilu serentak menuntut partai politik menggunakan strategi yang 
berbeda dalam memenangkan pemilu. Hal ini sebagaimana dikemukakan oleh (Sartori, 2007: 23-24), bahwa perubahan sistem pemilu akan membawa perubahan cara berkompetisi dan mempengaruhi karakter kompetitif dari partai politik.

Apalagi dalam pemilu serentak terdapat coattail effect. Apabila partai termasuk dalam gerbong calon Presiden yang memperoleh dukungan mayoritas dari masyarakat akan mendapatkan keuntungan dalam pemilihan umum legislatif, namun sebaliknya, bila kandidat presiden yang diusung kurang populer di masyarakat akan berdampak pada kurangnya simpatisan partai.

\section{Peluang dan Tantangan Bagi Penyelenggara Pemilu}

Peluang adanya pemilu serentak bagi penyelenggara pemilu adalah efisiensi biaya pemilu itu sendiri. Dalam konteks Indonesia, penyelenggara pemilu meliputi KPU dan Bawaslu yang dalam pelaksanaan tugasnya secara etis dikontrol oleh Dewan Kehormatan Penyelenggara Pemiu (DKPP). KPU bertanggung jawab atas penyelenggaraan pemilu mulai dari pendataan pemilih, menerima dan memvalidasi nominasi kontestan pemilu baik partai politik maupun kandidat, melaksanakan pemilu, perhitungan suara dan rekapitulasi suara. Sementara Bawaslu bertugas mengawasi pelaksanaan pemilu agar sesuai dengan asas pemilu yang langsung, umum, bebas, rahasia, jujur dan adil. Dalam pelaksanaan peran dan fungsi tersebut tentunya terkait banyak aspek teknis pemilu dan manajemen pemilu yang harus dilakukan. Sistem pemilu yang berbeda membutuhkan pengaturan dan persiapan serta manajemen pemilu yang berbeda. Peluang terbesar dari penyelenggara pemilu dengan dilaksanakannya pemilu serentak adalah efisiensi anggaran pemilu, karena pemilu tidak lagi dilaksanakan berkali kali.

Sedangkan tantangannya, perubahan sistem pemilu dari pemilu bertahap menjadi pemilu serentak membawa konsekuensi teknis penyelenggaraan pemilu yang cukup besar. Pelaksanaan pemilu serentak membutuhkan kapabilitas dan profesionalitas penyelenggara pemilu yang baik. Meskipun pemilu serentak rentang waktu pelaksanaan pemilu menjadi lebih pendek dan penggunaan anggaran lebih efisien, namun persiapan penyelenggaraan pemilu membutuhkan waktu yang cukup panjang. Aspek teknis penyelenggaraan pemilu menjadi lebih rumit. Logistik pemilu menjadi lebih banyak, sehingga harus dipersiapkan secara matang agar pelaksanaan pemilu tidak mengalami hambatan. Masalah kapabitas penyelenggara pemilu ini sangat penting untuk suksesnya pemilu serentak. Hal ini sebagaimana dikemukakan oleh Reynolds, dkk. (2008: 124), bahwa apabila terdapat permasalahan kapabilitas dalam menangani logistik, pemilu legislatif dan pemilu presiden secara terpisah merupakan pilihan.

Pemilu serentak juga membutuhkan kertas suara yang lebih banyak, serta waktu yang dibutuhkan pemilih di dalam bilik suara menjadi lebih banyak. Oleh karena itu penyelenggara pemilu dituntut untuk bisa mendesain surat suara yang lebih sederhana.

Selain itu, sosialisasi kepada pemilih harus dilaksanakan secara lebih luas baik dari segi kualitas maupun kuantitasnya agar tetap tercipta pemilu yang berkualitas pula.

Beberapa tantangan lain dalam penyelenggaraan pemilu serentak terkait dengan penyederhanaan dalam penyelenggaraan pemilu adalah perubahan sistem pemilu yang berbasis pada pilihan partai (sistem proporsional daftar tertutup) dan penyederhanaan system kepartaian, serta penataan 
kembali daerah penelitian. Aspek sinkronisasi Undang-Undang, tertama UU Pemilihan umum presiden, UU Pemilu dan UU Partai politik, juga menjadi sangat penting bagi penyelenggara pemilu. Semua kebijakan yang mendukung penyelenggaraan pemilu serentak akan terwujud apabila penyelenggara pemilu menjalin kerjasama yang baik dengan DPR dan Pemerintah.

Selain memperhatikan peluang dan tantangan pemilu serentak di atas, secara teknis, hambatan penyelenggaraan Pemilu Serentak 2019 harus bisa menghitung dan menjawab persoalan tentang norma pengaturan pemilu serentak itu; jadwal, tahapan dan program, termasuk pola rekrutmen penyelenggara pemilu sampai ke tingkat bawah yang tidak mengganggu berlangsungnya jadwal, tahapan dan program satu siklus pemilu utuh, sampai soal eksekusi di lapangan yang melibatkan pengamanan pemilunya (penyelenggara, logistik, proses pemilu, pengumuman hasil, pelantikan). Sepanjang semua hal teknisnya diperhitungkan dan pengaturan dasarnya dimuat dalam ketentuan undang-undang, pelaksanaan teknisnya tidak akan ada masalah yang berarti.

Untuk meminimalisir hambatan dalam penyelenggaraan Pemilu Serentak 2019, beberapa hal (upaya) yang dapat dilakukan adalah adanya undang-undang Pemilu Serentak yang mengatur garis besar penyelenggaraan Pemilu Serentak itu. Tidak perlu rigid (kaku) karena ini yang akan dituangkan dalam peraturan KPU. Koordinasi dengan berbagai pihak yang berhubungan dengan pemilu, tentu menjadi hal yang harus selalu dijalin bahkan sejak saat ini.

\section{Penutup}

Berdasarkan pembahasan di atas, dapatlah dikemukakan bahwa dilihat dari perspektif politik, pemilu nasional serentak memiliki sejumlah keuntungan yang bersifat hipotetik dilihat dari sisi pelembagaan politik dan konsolidasi demokrasi di Indonesia. Pertama, Pemilu nasional serentak bertujuan menciptakan hasil pemilu yang kongruen. Secara akademis konsep pemilu serentak ini hanya memungkinkan berlaku dalam sistem pemerintahan presidensial. Inti konsep ini adalah menggabungkan pelaksanaan pemilu legislatif dan eksekutif dalam satu hari yang sama, sehingga kemungkinan terciptanya pemerintahan yang kongruen, maksudnya terpilihnya pejabat eksekutif (Presiden dan Wakil Presiden) yang mendapat dukungan legislatif sehingga pemerintahan stabil dan efektif. kongruensi dapat tercipta karena dalam pemilu serentak terdapat efek yang namanya coattail effect, di mana keterpilihan calon presiden akan mempengaruhi keterpilihan calon legislatif. Artinya, orang setelah memilih capres akan cenderung memberikan pilihannya terhadap legislatif yang berasal dari partai yang mengusung presiden.

Kedua, pemilu nasional serentak ini mendorong terciptanya koalisi berbasis kebijakan, sebab pemilu juga membutuhkan partai politik yang kuat dan daya tahan memadai dalam mewakili kepentingan masyarakat dan menawarkan pilihan-pilihan kebijakan untuk menunjukkan kemampuannya dalam menuju kebaikan umum dan sekaligus meminimalkan pragmatisme politik yang kerap menjadi acuan aktor-aktor dan partai-partai politik dalam berkoalisi. Dengan pemilu serentak, parpol diyakini tak bisa lagi berkoalisi secara pragmatis. Parpol akan lebih selektif mencari calon, dan tak sekadar mengandalkan pertimbangan matematis. Dalam jangka panjang, hal ini diharapkan bermuara pada penyederhanaan sistem kepartaian secara alamiah. 
Ketiga, Pemilu nasional serentak mendorong kualitas Parpol yang lebih demokratis. Kehadiran dan peran partai politik saat ini menjadi prasyarat penting bagi praktik demokrasi modern, bahkan demokrasi modern adalah demokrasi partai. Sebagai saluran utama pengajuan pasangan calon presiden dan wakil presiden, demokratisasi internal partai politik menjadi sebuah keniscayaan. Artinya, pasangan calon yang diajukan harus berasal dari hasil sebuah proses yang terbuka dan partisipatif. Dengan cara seperti itu, posisi sentral di partai politik tidak otomatis menjadi jalan tol menjadi calon presiden dan/atau wakil presiden. Melihat realitas empirik selama ini, mengharapkan semua partai politik untuk lebih demokratis. Karena itu, tidak ada pilihan lain, kecuali Undang-undang tentang Partai Politik memberikan paksaan yang tak mungkin dihindari. Dalam hal ini, undang-undang tersebut harus menentukan kerangka dasar keterbukaan proses pengajuan pasangan calon. Jika perlu, sekiranya tidak melakukan proses terbuka dan partisipatif, partai politik bersangkutan kehilangan haknya mengajukan pasangan calon.

Keempat, pemilu nasional serentak potensial meminimalkan konflik antar partai atau pendukung partai. Konflik tak lagi berkepanjangan sepanjang tahun, sehingga dari sisi manajemen konflik jadi lebih mudah untuk ditangani. Energi pendukung partai dapat diarahkan untuk kegiatan positif lain yang mengarah pada pelembagaan partai politik. Bahkan pemilu nasional serentak lebih efisien, hemat waktu dan hemat biaya. Efisiensi dalam konteks pemilu serentak ini bisa dilihat dari beberapa aspek, antara lain efisiensi waktu dan biaya pemilu. Selanjutnya dalam aspek efisiensi biaya politik, karena biaya kampanye caleg dan capres jadi satu maka politik biaya tinggi sebagaimana praktik yang terjadi saat ini bisa diminimalkan. Dampak positif lebih lanjut, berpotensi kurangi money politics dan korupsi. Selain itu, dengan pemilu nasional serentak akan terjadi perubahan drastis mengenai presidential threshold, sebab semua partai politik yang lolos menjadi peserta pemilu akan bisa mengajukan calon presiden dan calon wakil presiden. Bahkan, bisa jadi akan masuk juga calon presiden independen. []

\section{Ucapan Terima Kasih}

Penulis ucapkan terima kasih terhadap rekan-rekan penulis di Departemen Ilmu Politik, Fakultas Ilmu Sosial dan Ilmu Politik, Universitas Padjadjaran yang telah menjadi teman diskusi selama penulisan naskah ini.

\section{Pendanaan}

Penulis tidak menerima bantuan pembiayaan untuk penelitian, kepenulisan (authorship), dan publikasi dari pihak manapun.

\section{Daftar Pustaka}

Hanan, D. (2016). Memperkuat Presidensialisme Multipartai di Indonesia: Pemilu Serentak, Sistem Pemilu dan Sistem Kepartaian. Jurnal Universitas Paramadina, 13, 1451-1475.

Haris, S., Surbakti, R., Bhakti, I. N., Isra, S., Ambardi, K., Harjanto, N., .. Nurhasim, M. (2014). Pemilu Nasional Serentak 2019. Diakses dari http://www.rumahpemilu.com/public/ doc/2015_02_06_01_35_09_EXECUTIVE SUMMARY PEMILU SERENTAK 2019.pdf 
Hayat, H. (2014). Korelasi Pemilu Serentak dengan Multi Partai Sederhana Sebagai Penguatan Sistem Presidensial. Jurnal Konstitusi, 11(3), 468-491. Diakses dari ejournal.mahkamahkonstitusi. go.id/index.php/jk/article/view/36/0

Madariaga, G. A., \& Ozen, H. E. (2015). Looking for two-sided coattail effects: Integrated parties and multilevel elections in the U.S. Electoral Studies, 40, 66-75. https://doi.org/10.1016/j. electstud.2015.06.006

Prasetyoningsih, N. (2014). Dampak Pemilihan Umum Serentak bagi Pembangunan Demokrasi Indonesia. Jurnal Media Hukum, 21(2), 241-263. Diakses dari http://journal.umy.ac.id/index. $\mathrm{php/jmh/article/download/1190/1251}$

Purnamasari, D. (2017). Tren Tingkat Partisipasi Pemilu dan Pilkada di Jakarta - Tirto.ID. Diakses pada 16 Juli 2018, dari https://tirto.id/tren-tingkat-partisipasi-pemilu-dan-pilkada-di-jakartaciDB

Putusan Mahkamah Konstitusi, R. I. (2013). Nomor 14/PUU-XI/2013 Perihal Pengujian UndangUndang Nomor 42 Tahun 2008 tentang Pemilihan Umum Presiden dan Wakil Presiden. Diakses dari http://www.bphn.go.id/data/documents/7.7._perkara_nomor_14-puu-2013_23_ jan_2014_pemilu_presiden_(.pdf

Reynolds, A., Reilly, B., \& Ellis, A. (2008). Electoral System Design: The New International IDEA Handbook. Stockholm: Idea International. Diakses dari http://www.idea.int/publications/esd/ upload/ESD_Handb_low.pdf

Sartori, G. (2007). The party-effects of electoral systems. In Israel Affairs (pp. 13-28). Routledge. https://doi.org/10.1080/13537129908719557

Shubhan, H. (2006). Recall: Antara Hak Partai Politik dan Hak Berpolitik Anggota Parpol. Jurnal Konstitusi, 3(4), 3057. Diakses dari http://lib.law.ugm.ac.id/ojs/index.php/jko/article/view/916

Stockemer, D., \& Calca, P. (2014). Presidentialism and voter turnout in legislative elections. Parliamentary Affairs, 67(3), 561-583. https://doi.org/10.1093/pa/gss065

Surbakti, R., Supriyanto, D., \& Asy'ari, H. (2011). Merancang Sistem Politik Demokratis Merancang Sistem Politik Demokratis Menuju Pemerintahan Presidensial yang Efektif. Jakarta: Kemitraan bagi Pembaruan Tata Pemerintahan.

Wijayanti, S. N., \& Purwaningsih, T. (2015). Laporan Akhir Tahun Pertama Penelitian Hibah Bersaing: Desain Pemilihan Umum Nasional Serentak dalam Perspektif Hukum dan Politik. Yogyakarta. Diakses dari http://repository.umy.ac.id/bitstream/handle/123456789/2227/Laporan Akhir DESAIN PEMILIHAN UMUM NASIONAL SERENTAK DALAM PERSPEKTIF HUKUM DAN POLITIK. pdf? sequence $=1$ \&isAllowed $=y$

\section{Tentang Penulis}

Ratnia Solihah adalah dosen Departemen IImu Politik, Fakultas IImu Sosial dan IImu Politik, Universitas Padjadjaran. Penulis memiliki area riset seputar tema kepartaian, kepemiluan, dan sistem politik Indonesia. 